\title{
A Survey of Indonesian Students' Use of Dictionaries
}

\author{
Fallianda, English Department, Faculty of Humanities, \\ Airlangga University, Surabaya, Indonesia \\ (fallianda.yand@gmail.com)
}

\begin{abstract}
This article aims to define the profile of Indonesian speakers as dictionary users by utilizing a questionnaire-based research. The survey was distributed to university students who were studying English as a foreign language. The students fall into two groups with pre-intermediate and intermediate levels of English proficiency. They were instructed to complete the survey. The question items encourage students to report their consultation frequency of dictionary use, dictionary choices and ratings, and dictionary information needs. The findings confirmed that both pre-intermediate and intermediate students use bilingual dictionaries more often than monolingual dictionaries. The two groups show indifference towards the evaluation of different dictionary types, since learners rate bilingual dictionaries as good as monolingual dictionaries. The collected data offers insights into students' awareness and knowledge of various dictionary types in the Indonesian lexicographic context.
\end{abstract}

Keywords: DICTIONARY AWARENESS, DICTIONARY USE, INDONESIAN UNIVERSITY STUDENTS, PROFICIENCY LEVELS, QUESTIONNAIRE, PROFILE OF DICTIONARY USERS

Opsomming: 'n Opname van Indonesiese studente se gebruik van woordeboeke. In hierdie artikel word beoog om die profiel van Indonesiese sprekers as woordeboekgebruikers met behulp van vraelysgebaseerde navorsing te definieer. Die vraelys is gegee aan universiteitstudente wat Engels as vreemde taal bestudeer. Die studente kan volgens vaardigheid in Engels in twee groepe verdeel word, nl. dié met pre-intermediêre en dié met intermediêre vaardigheidsvlakke. Hulle het die opdrag gekry om die vraelys te voltooi. Die studente moet o.a. verslag doen oor hul frekwensie van woordeboekgebruik, woordeboekkeuses en -waardebepaling, en hul behoeftes rakende woordeboekinligting. Die bevindings het bevestig dat albei groepe studente (preintermediêr en intermediêr) meer dikwels tweetalige woordeboeke as eentalige woordeboeke gebruik. Die twee groepe maak geen onderskeid by die evaluering van verskillende woordeboektipes nie aangesien hulle tweetalige woordeboeke as net so goed as eentalige woordeboeke beskou. Die verkrygde data bied insig in die studente se bewustheid en kennis van verskillende woordeboektipes in die Indonesiese leksikografiese konteks.

Sleutelwoorde: WOORDEBOEKBEWUSTHEID, WOORDEBOEKGEBRUIK, INDONESIESE UNIVERSITEITSTUDENTE, VAARDIGHEIDSVLAKKE, VRAELYS, PROFIEL VAN WOORDEBOEKGEBRUIKERS 


\section{Introduction}

From all the specialisations in dictionary research, the so-called user-perspectives have made a significant contribution to facts about user awareness of the availability and usability of various kinds of dictionaries and other reference works (Müller-Spitzer, Domínguez Vázquez, Nied Curcio, Silva Dias and Wolfer 2018). This allows studies to assess dictionary culture in a particular language community to discover whether users are aware of the value and limitations of the dictionaries they use. There has been increasingly important dictionary research which focused on users' needs for and skills in acquiring dictionary information (Atkins and Varantola 1998; Béjoint 1981; Hatherall 1984; Lew 2004; Tomaszczyk 1979). Unfortunately, the majority of the research has been conducted in English-speaking countries. Against this background, research needs to be done into an Indonesian lexicographic context in which Indonesian speakers might have different ideas on dictionary use and its values (Kwary 2018). However, there has only been little empirical data on dictionary user research by Indonesian speakers.

With this in mind, we collected information about the Indonesian lexicographic tradition. Accordingly, we found that the government considers dictionaries as systems of information storage (Moeljadi, Kamajaya and Amalia 2017) while few researchers took an interest in users' considerations for using a specific type of dictionary (Amalia 2014; Yanto 2016). The reason for the lack of empirical data to define the profile of Indonesian dictionary users is probably that Indonesian speakers have not prioritized dictionaries as one of the necessary reference tools (Badan Bahasa Upayakan Leksikografi Berkembang di Indonesia 2017). Methodological issues emerge for collecting information about dictionary culture in a community where dictionary use must occur. Therefore, researchers can solve the problems by carefully choosing representatives to conduct the survey, such as university students or learners of the English language. In addition, as suggested by Hartmann (2000: 390), researchers should consider including all lexicographic information to raise dictionary awareness. The collected data will be valuable information since the results could contribute to enhance a dictionary culture among particular language communities.

\section{The study}

Several studies examining users' perspectives have explored specific issues, such as user attitudes, behaviours, preferences, difficulties, dictionary misuse, reference needs and reference skills (Nesi 2014). Examples of important studies include a few empirical studies before the 1980s, such as Tomaszczyk's (1979) and Baxter's (1980) research. They reported preferences for bilingual dictionaries by EFL learners and difficulty in understanding monolingual dictionaries. On the contrary, Béjoint (1981) found that most French students of English 
(96\% of them) possessed monolingual dictionaries as recommended by their tutors. There was also a massive project, the EURALEX and AILA Research Project into Dictionary Use (Atkins and Varantola 1998). The study presented how users from four linguistic communities regard different types of dictionaries; thus it was found that the users prefer bilingual dictionaries to help them with particular language tasks. The superiority of the bilingual type was also reported by Polish students in Lew's study (2004). The study found a very low consultation frequency of monolingual dictionaries across levels, except the advanced level. It was not surprising, therefore, to find that the students mostly consulted their dictionaries for meaning, English equivalents and Polish equivalents. Although the study of users' perspectives has made impressive progress, the majority of research tended to be conducted in English-speaking countries. None of the above-mentioned studies contributed to show dictionary culture among Indonesian speakers, especially in the higher education context in which dictionaries become one of the important reference tools to support their learning process.

\section{Methodology}

A questionnaire survey was distributed to eighty-eight students at Airlangga University, Indonesia. The participants were in their first year studying English language and literature. The university students were chosen as representatives of the study because dictionaries are seen to be one of the important reference materials to support their learning process. With this sampling method, the results of the study would provide a better understanding on how Indonesian students acknowledge the value and limitations of dictionaries. The students' levels were equivalent to the A2 and B1 levels of the CEFR (Common Framework of Reference for Languages). The two levels are commonly referred to as pre-intermediate and intermediate levels.

\subsection{The user questionnaire}

The students were instructed to complete the user questionnaire that was distributed in a paper format. For reasons of different lexicographic traditions, language skills, and exposure to dictionary types, two researchers might have had different research questions and this might have been reflected in question items and their formats. The questionnaire form (see Appendix 1) is almost self-explanatory. On the top right-hand corner, there was a small space for the student identification number which would provide information about the students' English proficiency levels. The students had been told that their participation in the study would not affect their grades and they are expected to answer all the questions truthfully. There were three sections which consisted of several details. 
Section A identifies how often the students use certain dictionary categories (Indonesian-English, English-Indonesian, and English-English). The question item gives a range of frequency options from 6-7 days a week, 5-4 days a week, 3-2 days a week, and 1-0 days a week).

Section $\mathbf{B}$ asks the students to rank the first, second, and third dictionaries they often use, then to give ratings (excellent, good, OK, poor, and awful) for each dictionary mentioned. For this item, the survey also provides information about dictionaries that are readily available in Indonesia (see Appendix 2). It was possible for the students to mention other kinds of dictionaries and rejected dictionaries they did not actually use. The question item is in the form of openended questions. The instruction has made it clear that the participants are encouraged to give as many details as they could (e.g. details about type, title, publisher, author, edition, or medium).

Section $C$ asks the participants to report how often they look for certain information in a dictionary. In this question item, the students were given frequency options of always, often, sometimes, seldom and never. The typical presentation and symbol for each lexicographic information type are given in case the participants cannot relate to different kinds of information given in dictionary entries.

\section{Results and discussion}

\subsection{Frequency of dictionary use}

In item $\mathrm{A} 1$ of the user questionnaire, the students were asked to identify how often they consult bilingual dictionaries in the direction of Indonesian-English. A detailed summary of the students' responses is presented in Table 1.

\begin{tabular}{|l|c|c|l|c|c|}
\hline \multicolumn{7}{|c|}{ Students' Levels } \\
\hline \multicolumn{2}{|c|}{ Pre-intermediate } & \multicolumn{1}{c|}{ Intermediate } \\
\hline Consultation Frequency & $\mathrm{n}$ & $\%$ & Consultation Frequency & $\mathrm{n}$ & $\%$ \\
\hline 6-7 days a week & 5 & $11 \%$ & $6-7$ days a week & 6 & $15 \%$ \\
\hline $4-5$ days a week & 8 & $18 \%$ & $4-5$ days a week & 11 & $27 \%$ \\
\hline 2-3 days a week & 19 & $42 \%$ & $2-3$ days a week & 9 & $22 \%$ \\
\hline $0-1$ day a week & 13 & $29 \%$ & $0-1$ day a week & 41 & $100 \%$ \\
\hline Total & 45 & $100 \%$ & Total & & $37 \%$ \\
\hline
\end{tabular}

Table 1: Frequency of Indonesian-English dictionary consultation by preintermediate and intermediate students

As shown in Table 1, the frequency use of Indonesian-English dictionaries increases across levels. However, the statistical results show no significant rela- 
tionship between the students' levels and the frequency. This means that both groups have a similar consultation frequency when using Indonesian-English dictionaries.

In item A2, the students' responses were collected to find how often bilingual dictionaries in the direction of English-Indonesian are consulted. A detailed breakdown of responses is presented in Table 2.

\begin{tabular}{|l|c|c|l|c|c|}
\hline \multicolumn{7}{|c|}{ Students' Levels } \\
\hline \multicolumn{2}{|c|}{ Pre-intermediate } & \multicolumn{1}{c|}{ Intermediate } \\
\hline \multicolumn{1}{|c|}{ Consultation Frequency } & $\mathrm{n}$ & $\%$ & \multicolumn{1}{|c|}{ Consultation Frequency } & $\mathrm{n}$ & 7 \\
\hline 6-7 days a week & 3 & $7 \%$ & $6-7$ days a week & 13 & $32 \%$ \\
\hline $4-5$ days a week & 12 & $27 \%$ & $4-5$ days a week & 13 & $32 \%$ \\
\hline 2-3 days a week & 19 & $42 \%$ & $2-3$ days a week & 8 & $20 \%$ \\
\hline $0-1$ day a week & 11 & $24 \%$ & $0-1$ day a week & 41 & $100 \%$ \\
\hline Total & 45 & $100 \%$ & Total & & 73 \\
\hline
\end{tabular}

Table 2: Frequency of English-Indonesian dictionary consultation by preintermediate and intermediate students

As shown in Table 2, even though there is a tendency of intermediate students to use English-Indonesian dictionaries more often than pre-intermediate students, there is no significant effect of different levels on the frequency of English-Indonesian dictionary consultation. From this fact, it is suggested that the groups show similar consultation frequency when using English-Indonesian dictionaries.

In item A3, the students responded to a question on how often they used monolingual English dictionaries. Table 3 below shows a detailed breakdown of the students' responses.

\begin{tabular}{|l|c|c|l|c|c|}
\hline \multicolumn{5}{|c|}{ Students' Levels } \\
\hline \multicolumn{1}{|c|}{ Pre-intermediate } & \multicolumn{3}{c|}{ Intermediate } \\
\hline Consultation Frequency & $\mathrm{n}$ & $\%$ & \multicolumn{1}{|c|}{ Consultation Frequency } & $\mathrm{n}$ & $\%$ \\
\hline 6-7 days a week & 3 & $7 \%$ & $6-7$ days a week & 0 & $0 \%$ \\
\hline 4-5 days a week & 5 & $11 \%$ & $4-5$ days a week & 7 & $18 \%$ \\
\hline 2-3 days a week & 16 & $35 \%$ & $2-3$ days a week & 22 & $56 \%$ \\
\hline 0-1 day a week & 22 & $48 \%$ & $0-1$ day a week & 39 & $100 \%$ \\
\hline Total & 46 & $100 \%$ & Total & 39 & 5 \\
\hline
\end{tabular}

Table 3: Frequency of monolingual English dictionary consultation by preintermediate and intermediate students 
As shown in Table 3, most of pre-intermediate and intermediate students reported using monolingual English dictionaries 0-1 day a week. This means that the two groups rarely use monolingual dictionaries. An interesting finding appears as the use of monolingual English dictionaries did not seem to increase across levels, indeed the consultation frequency seemed lower among intermediate students. The result of the statistical test, however, shows no significant difference between the students' levels. Therefore, this means that none of the groups used monolingual English dictionaries more often than the other.

It was expected that the students with a higher level would use monolingual dictionaries more often than those with a lower level of English proficiency. Let us now examine the effect of levels on the consultation frequency. The tendency that emerges from the test results has shown no significant effect $\left(\mathrm{R}^{2}=4 \%, p=0.29\right)$ of levels on frequency of dictionary use. We can conclude that the two groups of students have similar habits in using dictionaries, in which monolingual dictionaries are rarely used and English-Indonesian dictionaries are consulted as often as Indonesian-English dictionaries.

\subsection{Dictionary preference}

In section B of the user questionnaire, the students were asked to name three dictionaries they used most frequently. We had set the item by providing three possibilities consisting of three different kinds of dictionaries from which to choose to complete it. Moreover, the three possibilities in the questionnaire are provided to emphasize the students' first choice (item B1), second choice (item B2), and third choice (item B3). A detailed number and percentage of students' responses are separately presented in tables for each level of English proficiency.

From 73 valid responses collected from pre-intermediate students, 42 preintermediate students reported using at least one dictionary. Half of pre-intermediate students reported using two dictionaries, while 10 students were identified using three dictionaries to help them with their day-to-day learning process. In Table 4, we provide readers with details of dictionaries mentioned by preintermediate students.

\begin{tabular}{|c|l|c|c|c|c|c|}
\hline No. & \multicolumn{1}{|c|}{ Dictionary Code } & $\begin{array}{c}\text { 1st } \\
\text { Choice }\end{array}$ & $\begin{array}{c}\text { 2nd } \\
\text { Choice }\end{array}$ & $\begin{array}{c}\text { 3rd } \\
\text { Choice }\end{array}$ & Total & Percent \\
\hline 1. & OALD & 16 & 3 & 0 & 19 & $24 \%$ \\
\hline 2. & Google Translate & 10 & 4 & 0 & 14 & $18 \%$ \\
\hline 3. & $\begin{array}{l}\text { Kamus Indonesia-Inggris/Kamus } \\
\text { Inggris-Indonesia }\end{array}$ & 4 & 3 & 3 & 10 & $13 \%$ \\
\hline 4. & Kamusku & 6 & 1 & 2 & 9 & $11 \%$ \\
\hline 5. & $\begin{array}{l}\text { Kamus Indonesia-Inggris/Kamus } \\
\text { Inggris-Indonesia (Echols and }\end{array}$ & 2 & 4 & 1 & 7 & $9 \%$ \\
\hline 6. & CALD & 0 & 1 & 1 & 2 & $3 \%$ \\
\hline
\end{tabular}




\begin{tabular}{|c|l|c|c|c|c|c|}
\hline 7. & Line Dictionary & 0 & 2 & 0 & 2 & $3 \%$ \\
\hline 8. & LDCE & 1 & 1 & 0 & 2 & $3 \%$ \\
\hline 9. & Merriam Webster & 1 & 1 & 0 & 2 & $3 \%$ \\
\hline 10. & COBUILD & 1 & 0 & 0 & 1 & $1 \%$ \\
\hline 11. & Dictionary.com & 0 & 0 & 1 & 1 & $1 \%$ \\
\hline 12. & $\begin{array}{l}\text { English monolingual diction- } \\
\text { ary }\end{array}$ & 0 & 1 & 0 & 1 & $1 \%$ \\
\hline 13. & Flitto & 0 & 0 & 1 & 1 & $1 \%$ \\
\hline 14. & $\begin{array}{l}\text { Kamus Password English } \\
\text { Learner's Dictionary for } \\
\text { Speakers of Bahasa Indonesia }\end{array}$ & 0 & 0 & 1 & 1 & $1 \%$ \\
\hline 15. & U-Dictionary & 1 & 0 & 0 & 1 & $1 \%$ \\
\hline 16. & Total & 42 & 21 & 10 & 73 & $100 \%$ \\
\hline
\end{tabular}

Table 4: Dictionaries most often used by pre-intermediate students

As shown in Table 4, the OALD is reported to be the most consulted dictionary, as 16 intermediate students claimed to use it as their first choice and 3 additional students preferred to use it as their second choice. The second- and thirdranking lists belong to Google Translate which is better known than unidentified formats of Kamus Indonesia-Inggris/Inggris-Indonesia. In the fourth and fifth ranks, there are Kamusku, an electronic and off-line bilingual dictionary and Kamus Indonesia-Inggris/Kamus Inggris-Indonesia (Echols and Shadily 2014/2017), one of the printed bilingual dictionaries widely available in Indonesia. The current findings confirmed the domination of OALD for many years in both dictionary sales and teaching practices in the EFL context. In Table 5, we present the summary of dictionary preferences, whether dictionaries are categorized as monolingual or bilingual dictionaries.

\begin{tabular}{|l|c|c|c|c|}
\hline Dictionary types & 1st choice & 2nd choice & 3rd choice & Total \\
\hline Bilingual & $23(54.8 \%)$ & $14(66.7 \%)$ & $8(80 \%)$ & $45(61.6 \%)$ \\
\hline Monolingual & $19(45.2 \%)$ & $7(33.3 \%)$ & $2(20 \%)$ & $28(38.4 \%)$ \\
\hline Total & $42(100 \%)$ & $21(100 \%)$ & $10(100 \%)$ & $73(100 \%)$ \\
\hline
\end{tabular}

Table 5: Monolingual versus bilingual dictionaries given as 1st, 2nd, and 3rd choice by pre-intermediate students

As shown in Table 5 above, we can see that more pre-intermediate students choose bilingual rather than monolingual dictionaries from the three possibilities. However, the result shows no significant difference between the prefer- 
ences for two dictionary types reported by pre-intermediate students. In other words, we can say that the pre-intermediate students did not favor one dictionary type over the other.

On the other hand, from the total of 72 valid responses by the intermediate students, 39 intermediate students used at least one dictionary. 24 intermediate students reported using two dictionaries, while 9 students claimed to use three dictionaries. In Table 6, we present the breakdown of responses across choices, as well as details of dictionaries mentioned by intermediate students.

\begin{tabular}{|c|c|c|c|c|c|c|}
\hline No. & Dictionary Code & $\begin{array}{l}\text { 1st } \\
\text { Choice }\end{array}$ & $\begin{array}{l}\text { 2nd } \\
\text { Choice }\end{array}$ & $\begin{array}{l}\text { 3rd } \\
\text { Choice }\end{array}$ & Total & Percent \\
\hline 1. & OALD & 13 & 3 & 1 & 17 & $22 \%$ \\
\hline 2. & Google Translate & 7 & 4 & 3 & 14 & $18 \%$ \\
\hline 3. & $\begin{array}{l}\text { Kamus Indonesia-Inggris/Kamus } \\
\text { Inggris-Indonesia (Echols and } \\
\text { Shadily 2014/2017) }\end{array}$ & 7 & 4 & 1 & 12 & $16 \%$ \\
\hline 4. & Kamusku & 4 & 5 & 0 & 9 & $12 \%$ \\
\hline 5. & $\begin{array}{l}\text { Oxford Mini Dictionary } \mathcal{E} \\
\text { Thesaurus }\end{array}$ & 2 & 2 & 0 & 4 & $5 \%$ \\
\hline 6. & $\begin{array}{l}\text { Kamus Indonesia-Inggris/ } \\
\text { Inggris-Indonesia }\end{array}$ & 2 & 1 & 0 & 3 & $4 \%$ \\
\hline 7. & English Thesaurus & 2 & 0 & 0 & 2 & $3 \%$ \\
\hline 8. & U-Dictionary & 1 & 0 & 1 & 2 & $3 \%$ \\
\hline 9. & Babla & 0 & 1 & 0 & 1 & $1 \%$ \\
\hline 10. & $\begin{array}{l}\text { Kamus Bilingual } 600 \text { Miliyar } \\
\text { Kata }\end{array}$ & 1 & 0 & 0 & 1 & $1 \%$ \\
\hline 11. & British Dictionary & 0 & 1 & 0 & 1 & $1 \%$ \\
\hline 12. & COBUILD & 0 & 1 & 0 & 1 & $1 \%$ \\
\hline 13. & $\begin{array}{l}\text { Electronic Dictionary } \\
\text { (bilingual) }\end{array}$ & 0 & 1 & 0 & 1 & $1 \%$ \\
\hline 14. & LDCE & 0 & 0 & 1 & 1 & $1 \%$ \\
\hline 15. & MEDAL & 0 & 0 & 1 & 1 & $1 \%$ \\
\hline 16. & Merriam Webster & 0 & 1 & 0 & 1 & $1 \%$ \\
\hline \multirow[t]{2}{*}{17.} & Urbandictionary.com & 0 & 0 & 1 & 1 & $1 \%$ \\
\hline & Total & 39 & 24 & 9 & 72 & $100 \%$ \\
\hline
\end{tabular}

Table 6: Dictionaries most often used by intermediate students

As shown in Table 6 above, the OALD remains the most frequent dictionary used by intermediate students. Of the total 17 responses, 13 students reported choosing the OALD as their first choice dictionary. The two front runner dictionaries are Google Translate and Kamus Indonesia-Inggris/Kamus Inggris-Indo- 
nesia (Echols and Shadily 2014/2017). Kamusku and Oxford Mini Dictionary E Thesaurus are the fourth and fifth most consulted dictionaries. In Table 7, readers can find the breakdown of students' preferences based on the classification of dictionary types, which are monolingual and bilingual dictionaries.

\begin{tabular}{|l|c|c|c|c|}
\hline Dictionary types & 1st choice & 2nd choice & 3rd choice & Total \\
\hline Bilingual & $22(56.4 \%)$ & $16(66.7 \%)$ & $5(55.6 \%)$ & $43(60 \%)$ \\
\hline Monolingual & $17(43.6 \%)$ & $8(33.3 \%)$ & $4(44.4 \%)$ & $29(40 \%)$ \\
\hline Total & $39(100 \%)$ & $24(100 \%)$ & $9(100 \%)$ & $72(100 \%)$ \\
\hline
\end{tabular}

Table 7: Monolingual versus bilingual dictionaries given as 1st, 2nd, and 3rd choice by intermediate students

As shown in Table 7 above, intermediate students prefer to use bilingual dictionaries to monolingual ones. However, the statistical test has shown that there is no significant difference in the consultation frequency of consulting bilingual and monolingual dictionaries. In other words, we can say that among intermediate students they did not seem to prefer one type to the other.

An analysis of choices for individual dictionary types above suggests that bilingual dictionaries are consulted more often and are preferred by all of the students as their first choice. However, the effect of students' levels and dictionary choice need to be examined further. From the choices made in the test result, it was found that the effect of dictionary types was not significant, so the effect holds irrespective of the students' levels. From this fact, it was suggested the two groups of students did not favor one type of dictionary over the other. There also appears to be a tendency for the students to use one specific dictionary, that is Oxford.

\subsection{Dictionary evaluation}

In section B of the user questionnaire, the students were instructed to rate the dictionaries they have named before. The ratings were given in ranking order. The ratings are classified as 'excellent', 'good', 'OK', 'poor', and 'awful'. A detailed number of responses are separately presented in tables for each level of pre-intermediate (see Table 8) and intermediate levels (see Table 10). In Table 8, we collected 68 valid ratings identified by pre-intermediate students. 


\begin{tabular}{|c|c|c|c|c|c|c|c|c|}
\hline \multirow[b]{2}{*}{ No. } & \multirow[b]{2}{*}{ Dictionary Code } & \multirow{2}{*}{$\begin{array}{l}\text { Mean } \\
\text { Rating }\end{array}$} & \multicolumn{5}{|c|}{ Rating } & \multirow[b]{2}{*}{$\mathrm{n}$} \\
\hline & & & $\begin{array}{c}\text { Excell- } \\
\text { ent }\end{array}$ & Good & OK & Poor & Awful & \\
\hline 1. & OALD & 4.24 & 6 & 9 & 2 & 0 & 0 & 17 \\
\hline 2. & Google Translate & 3.54 & 0 & 9 & 2 & 2 & 0 & 13 \\
\hline 3. & Kamusku & 3.56 & 1 & 4 & 3 & 1 & 0 & 9 \\
\hline 4. & $\begin{array}{l}\text { Kamus Indonesia-Inggris/ } \\
\text { Inggris-Indonesia }\end{array}$ & 4.00 & 0 & 9 & 0 & 0 & 0 & 9 \\
\hline 5. & $\begin{array}{l}\text { Kamus Indonesia-Inggris/ } \\
\text { Kamus Inggris-Indonesia } \\
\text { (Echols and Shadily } \\
\text { 2014/2017) }\end{array}$ & 4.33 & 2 & 4 & 0 & 0 & 0 & 6 \\
\hline 6. & Line Dictionary & 3.00 & 0 & 1 & 0 & 1 & 0 & 2 \\
\hline 7. & LDCE & 4.00 & 0 & 2 & 0 & 0 & 0 & 2 \\
\hline 8. & CALD & 4.50 & 1 & 1 & 0 & 0 & 0 & 2 \\
\hline 9. & Merriam Webster & 4.50 & 1 & 1 & 0 & 0 & 0 & 2 \\
\hline 10. & Dictionary.com & 3.00 & 0 & 0 & 1 & 0 & 0 & 1 \\
\hline 11. & English Dictionary & 3.00 & 0 & 0 & 1 & 0 & 0 & 1 \\
\hline 12. & COBUILD & 4.00 & 0 & 1 & 0 & 0 & 0 & 1 \\
\hline 13. & Flitto & 4.00 & 0 & 1 & 0 & 0 & 0 & 1 \\
\hline 14. & U-Dictionary & 4.00 & 0 & 1 & 0 & 0 & 0 & 1 \\
\hline 15. & $\begin{array}{l}\text { Kamus Password English } \\
\text { Learner's Dictionary for } \\
\text { Speakers of Bahasa } \\
\text { Indonesia }\end{array}$ & 5.00 & 1 & 0 & 0 & 0 & 0 & 1 \\
\hline 16. & Total & & 12 & 43 & 9 & 4 & 0 & 68 \\
\hline 17. & Mean rating & 3.56 & & & & & & \\
\hline
\end{tabular}

Table 8: Mean ratings and breakdown of rating responses by dictionary category chosen by pre-intermediate students

As shown in Table 8, the five top rows from the collected data give information about the most consulted dictionary. The mean rating of each dictionary is also given in the table. The smaller the number of dictionaries rated by pre-intermediate students, the less reliable the ratings were. However, the identification of the least consulted dictionary is still given for completeness.

From the facts collected and presented in Table 8 above, 17 pre-intermediate students rated the OALD dictionary as 'excellent' and 'good'. The average rating of the OALD is 4.24. This fact complements our previous finding that the OALD is not only preferred, but also highly valued by pre-intermediate students. From the total of 13 pre-intermediate students, nine of them rated Google Translate as 'good'. Google Translate obtained a mean rating of 3.54. The mean ratings received by Kamusku and Kamus Indonesia-Inggris/Inggris-Indonesia are 3.56 
and 4.00 respectively. Kamus Indonesia-Inggris/Kamus Inggris-Indonesia (Echols and Shadily 2014/2017) could only be identified by fewer pre-intermediate students and received an average score of 4.33 , which is surprisingly higher than the OALD. However, the OALD's rating is considered to be more reliable than that of Kamus Indonesia-Inggris/Kamus Inggris-Indonesia (Echols and Shadily 2014/2017). The reason for this is that the less variation a dictionary has, the lower the mean error value of it will be.

There is one interesting case in which the semi-bilingual dictionary (i.e. Kamus Password English Learner's Dictionary for Speakers of Bahasa Indonesia) (Kwary 2011) was identified by one of the pre-intermediate students. This finding is quite surprising, as we can see in Yanto's (2016) study that the dictionary was hardly mentioned by Indonesian lecturers in the English department. As there is only one student who could identify the dictionary, this finding is unreliable in which the mean error value could be the highest.

All the dictionaries rated in Table 8 above can be classified into either bilingual or monolingual dictionaries. A summary of the results is given in Table 9 below. The table presents information about the mean ratings, standard errors, and 95\% confidence intervals for both bilingual and monolingual dictionaries.

\begin{tabular}{|l|c|c|c|c|c|}
\hline Dictionary types & Mean Rating & Std. Error & $-95 \%$ & $+95 \%$ & $\mathrm{n}$ \\
\hline Bilingual & 3.79 & 1.46 & 3.12 & 4.45 & 42 \\
\hline Monolingual & 4.15 & 1.35 & 3.55 & 4.76 & 26 \\
\hline
\end{tabular}

Table 9: Pre-intermediate students' ratings of bilingual and monolingual dictionaries

As shown in Table 9 above, although pre-intermediate students claimed to use bilingual dictionaries more than monolingual ones (see Section 4.2), it emerged that monolingual dictionaries received higher ratings than bilingual ones. The statistical result suggests that there was no significant effect of dictionary types on their ratings. The data somewhat confirms the fact that pre-intermediate students not only use both bilingual and monolingual dictionaries but also value both dictionaries.

Let us examine the ratings given by intermediate students. There were 67 valid responses in the students' evaluation. Table 10 below displays the mean ratings of dictionaries identified by the intermediate students. 


\begin{tabular}{|c|c|c|c|c|c|c|c|c|}
\hline \multirow[b]{2}{*}{ No. } & \multirow[b]{2}{*}{ Dictionary Code } & \multirow[b]{2}{*}{$\begin{array}{l}\text { Mean } \\
\text { Rating }\end{array}$} & \multicolumn{5}{|c|}{ Rating } & \multirow[b]{2}{*}{$\mathrm{n}$} \\
\hline & & & $\begin{array}{c}\text { Excell- } \\
\text { ent }\end{array}$ & Good & OK & Poor & Awful & \\
\hline 1. & OALD & 4.31 & 6 & 9 & 1 & 0 & 0 & 16 \\
\hline 2. & Google Translate & 3.20 & 1 & 8 & 3 & 2 & 0 & 14 \\
\hline 3. & $\begin{array}{l}\text { Kamus Indonesia-Inggris/ } \\
\text { Kamus Inggris-Indonesia } \\
\text { (Echols and Shadily } \\
\text { 2014/2017) }\end{array}$ & 4.30 & 4 & 8 & 0 & 0 & 0 & 12 \\
\hline 4. & Kamusku & 2.70 & 2 & 4 & 2 & 1 & 0 & 9 \\
\hline 5. & $\begin{array}{l}\text { Oxford Mini Dictionary } \mathcal{E} \\
\text { Thesaurus }\end{array}$ & 4.25 & 1 & 3 & 0 & 0 & 0 & 4 \\
\hline 6. & U-Dictionary & 4.00 & 0 & 2 & 0 & 0 & 0 & 2 \\
\hline 7. & English Thesaurus & 4.50 & 1 & 1 & 0 & 0 & 0 & 2 \\
\hline 8. & $\begin{array}{l}\text { Kamus Bilingual } 600 \text { Miliyar } \\
\text { Kata }\end{array}$ & 3.00 & 0 & 0 & 1 & 0 & 0 & 1 \\
\hline 9. & LDCE & 3.00 & 0 & 0 & 1 & 0 & 0 & 1 \\
\hline 10. & Babla & 4.00 & 0 & 1 & 0 & 0 & 0 & 1 \\
\hline 11. & Urbandictionary.com & 4.00 & 0 & 1 & 0 & 0 & 0 & 1 \\
\hline 12. & COBUILD & 5.00 & 1 & 0 & 0 & 0 & 0 & 1 \\
\hline 13. & MEDAL & 5.00 & 1 & 0 & 0 & 0 & 0 & 1 \\
\hline 14. & Merriam Webster & 5.00 & 1 & 0 & 0 & 0 & 0 & 1 \\
\hline 15. & Kamus Aplikasi (Bilingual) & 5.00 & 1 & 0 & 0 & 0 & 0 & 1 \\
\hline 16. & Total & & 19 & 37 & 8 & 3 & 0 & 67 \\
\hline 17. & Mean rating & 4.34 & & & & & & \\
\hline
\end{tabular}

Table 10: Mean ratings and breakdown of rating responses by dictionary category chosen by intermediate students

As shown in Table 10, the OALD is mostly consulted and highly rated by intermediate students. The dictionary was also rated as 'excellent' and 'good' and receives an average rating of 4.31 . Google Translate, which is in the second place as the most consulted dictionary, received a mean score of 3.20. Kamus Indonesia-Inggris/Kamus Inggris-Indonesia (Echols and Shadily 2014/2017) and Kamusku obtained average rating scores of 4.30 and 2.70 respectively.

There is an interesting finding that can be seen in the breakdown of responses given in Table 10. We can see that the five top lists start with a monolingual dictionary by a specific publisher (i.e. Oxford Advanced Learner's Dictionary) and end with a smaller dictionary by the same publisher (i.e. Oxford Mini Dictionary \& Thesaurus). Four intermediate students rated Oxford Mini Dictionary $\mathcal{E}$ Thesaurus quite highly, with an average rating of 4.25 . This dictionary was not even mentioned by the pre-intermediate students. Although the number is small, this provides more information about the students' awareness of different kinds of dictionaries.

A further analysis has to be done to see whether there is a significant effect of dictionary types on the ratings. Table 11 gives detailed information about mean 
ratings, standard errors, and 95\% confidence intervals for each dictionary type.

\begin{tabular}{|l|c|c|c|c|c|}
\hline Dictionary type & Mean Rating & Std. Error & $-95 \%$ & $+95 \%$ & $\mathrm{n}$ \\
\hline Bilingual & 3.88 & 1.40 & 3.28 & 4.48 & 42 \\
\hline Monolingual & 4.34 & 1.31 & 3.84 & 4.85 & 29 \\
\hline
\end{tabular}

Table 11: Intermediate students' ratings of bilingual and monolingual dictionaries

As shown in Table 11, intermediate students valued monolingual dictionaries more than bilingual dictionaries. However, there is no significant effect of dictionary types on the evaluation. We can assume that the two groups evaluate both dictionaries similarly.

\section{Reference needs}

In section $C$ of the user questionnaire, the students were asked to report how often they consult their dictionaries to look for particular information. We considered including seven main types of dictionary information in the questionnaire. They are meaning, pronunciation, word class, examples, phrases, context, and synonyms. The options of consultation frequency were made to elicit relative frequency.

\begin{tabular}{|c|c|c|c|c|c|c|c|c|c|c|c|}
\hline \multirow{3}{*}{\multicolumn{2}{|c|}{$\begin{array}{c}\text { Types of } \\
\text { Information }\end{array}$}} & \multicolumn{10}{|c|}{ Levels } \\
\hline & & \multicolumn{5}{|c|}{ Pre-intermediate } & \multicolumn{5}{|c|}{ Intermediate } \\
\hline & & \multirow{2}{*}{$\begin{array}{l}\mathrm{Al} \\
27\end{array}$} & \multirow{2}{*}{$\begin{array}{l}\text { Of } \\
11\end{array}$} & \multirow{2}{*}{$\begin{array}{c}\text { So } \\
8\end{array}$} & \multirow{2}{*}{$\begin{array}{c}\mathrm{Se} \\
0\end{array}$} & \multirow{2}{*}{$\begin{array}{c}\mathrm{Ne} \\
0\end{array}$} & \multirow{2}{*}{$\begin{array}{l}\mathrm{Al} \\
17\end{array}$} & \multirow{2}{*}{$\begin{array}{l}\text { Of } \\
19 \\
\end{array}$} & \multirow{2}{*}{$\begin{array}{c}\text { So } \\
4\end{array}$} & \multirow{2}{*}{$\begin{array}{c}\mathrm{Se} \\
1\end{array}$} & \multirow{2}{*}{$\begin{array}{c}\mathrm{Ne} \\
1\end{array}$} \\
\hline C1. Mn & $\mathrm{n}$ & & & & & & & & & & \\
\hline C1:Mng & $\%$ & $58.7 \%$ & $24 \%$ & $17.4 \%$ & $0 \%$ & $0 \%$ & $40.5 \%$ & $45.2 \%$ & $9.5 \%$ & $2.4 \%$ & $2.4 \%$ \\
\hline \multirow{2}{*}{ C2: Pron } & $\mathrm{n}$ & 4 & 15 & 18 & 8 & 1 & 6 & 8 & 16 & 11 & 1 \\
\hline & $\%$ & $8.7 \%$ & $32.6 \%$ & $39 \%$ & $17.4 \%$ & $2.2 \%$ & $14.3 \%$ & $19.0 \%$ & $38.1 \%$ & $26.2 \%$ & $2.4 \%$ \\
\hline \multirow{2}{*}{ C3: WdCl } & $\mathrm{n}$ & 2 & 17 & 14 & 8 & 5 & 4 & 7 & 14 & 15 & 2 \\
\hline & $\%$ & $4.3 \%$ & $37 \%$ & $30.4 \%$ & $17.4 \%$ & $11 \%$ & $9.5 \%$ & $16.7 \%$ & $33.3 \%$ & $36 \%$ & $4.8 \%$ \\
\hline \multirow{2}{*}{ C4: Exm } & $\mathrm{n}$ & 4 & 6 & 20 & 13 & 3 & 5 & 11 & 16 & 6 & 4 \\
\hline & $\%$ & $8.7 \%$ & $13 \%$ & $43.5 \%$ & $28.3 \%$ & $6.5 \%$ & $12 \%$ & $26.2 \%$ & $38.1 \%$ & $14.3 \%$ & $9.5 \%$ \\
\hline \multirow{2}{*}{ C5: Phrs } & $\mathrm{n}$ & 2 & 4 & 8 & 22 & 10 & 1 & 3 & 26 & 9 & 2 \\
\hline & $\%$ & $4.3 \%$ & $8.7 \%$ & $17.4 \%$ & $47.8 \%$ & $22 \%$ & $2.4 \%$ & $7.3 \%$ & $63 \%$ & $22 \%$ & $4.9 \%$ \\
\hline \multirow{2}{*}{ C6: Con } & $\mathrm{n}$ & 5 & 8 & 18 & 10 & 5 & 1 & 6 & 12 & 17 & 6 \\
\hline & $\%$ & $10.9 \%$ & $17.4 \%$ & $39 \%$ & $22 \%$ & $11 \%$ & $2.4 \%$ & $14.3 \%$ & $28.6 \%$ & $40.5 \%$ & $14.3 \%$ \\
\hline \multirow{2}{*}{ C7: Syn } & $\mathrm{n}$ & 5 & 8 & 18 & 10 & 5 & 6 & 16 & 18 & 2 & 0 \\
\hline & $\%$ & $11 \%$ & $17.4 \%$ & $39 \%$ & $22 \%$ & $11 \%$ & $14.3 \%$ & $38 \%$ & $43 \%$ & $4.8 \%$ & $0 \%$ \\
\hline $\begin{array}{l}\text { C8: Usage } \\
\text { notes }\end{array}$ & $\mathrm{n}$ & 0 & 0 & 0 & 0 & 0 & 0 & 1 & 0 & 0 & 0 \\
\hline
\end{tabular}

Table 12: The breakdown of students' responses for reference needs by preintermediate and intermediate students 
As shown in Table 12, the most consulted information when the students use dictionaries is word meaning. The concept of meaning in the questionnaire referred to English and Indonesian equivalents, as well as an English definition. For this item, we considered that it was not necessary to mention the concept of word meanings separately. Indeed, more than $80 \%$ of the students reported to 'always' or 'often' look for meaning. A breakdown of responses for each level is also given here: 27 pre-intermediate learners (58.7\%) reported that they 'always' look for meaning in a dictionary and 11 of them $(24 \%)$ claimed they 'often' look for meaning. In contrast, 17 intermediate students (40.5\%) reported that they 'always' look for meaning in a dictionary, while more intermediate students $(45.2 \%)$ chose the 'often' option. Fewer intermediate students $(4 \%)$ claimed they 'seldom' or 'never' consult a dictionary for meaning, while none of the pre-intermediate students chose the last two options ('seldom' and 'never'). It is interesting to see that students with a higher level of English proficiency rely on the consultation of meaning in a dictionary, while pre-intermediate students seemed to be confident enough of their vocabulary knowledge to consult dictionaries for meaning.

In item C 2 of the questionnaire, around $40 \%$ of both pre-intermediate and intermediate students indicated that they need to consult dictionaries to pronounce words correctly. This also means that more than $40 \%$ of both preintermediate and intermediate students might be confident enough not to consult their dictionaries for the way to pronounce English words. More reasons possibly emerge from the students. In item C3, the students were asked to report how often they consult their dictionaries to find word class information. It is suggested that there was a tendency for pre-intermediate students to choose 'always' and 'often' options. In contrast, intermediate students tend to choose the two lower frequency options, 'seldom' and 'never'. We can thus assume that the frequency of word-class consultation in dictionaries may decrease as students' proficiency levels rise.

In item C4, pre-intermediate students reported lower consultation $(>50 \%$ of all responses) of example information in dictionary entries. In contrast, more intermediate students reported consulting examples more often. In item C5 and item C6, the students were instructed to report their needs for phrases and context information in dictionaries. The responses from both pre-intermediate and intermediate students have shown that only a few students indicated that they 'always' or 'often' look for phrases and context in their dictionaries. For the last item C7, the students would indicate their consultation frequency of synonym information. It was found that more students in the pre-intermediate level chose the lower frequency options, while more students in the intermediate level chose the higher frequency options. The higher consultation for synonyms can be seen as additional information on word meaning, in addition to the fact that information on meaning is already given in the English definition or in the translation equivalents.

The comparison in the consultation frequency of dictionary information between the two groups of students is presented in Table 13 below. The 
responses of the students' reference needs are then ranked by mean scores of the consultation frequency.

\begin{tabular}{|c|l|c|c|c|l|c|c|}
\hline \multirow{2}{*}{ Rank } & \multicolumn{3}{|c|}{ Pre-intermediate Level } & \multirow{2}{*}{ Rank } & \multicolumn{3}{|c|}{ Intermediate Level } \\
\cline { 2 - 5 } \cline { 8 - 9 } & Information Type & Mean & $\begin{array}{c}\text { Std. } \\
\text { Dev. }\end{array}$ & & Information Type & Mean & $\begin{array}{c}\text { Std. } \\
\text { Dev. }\end{array}$ \\
\hline 1. & C1: Meaning & 4.35 & 0.99 & 1. & C1: Meaning & 4.19 & 0.89 \\
\hline 2. & C2: Pronunciation & 3.28 & 0.93 & 2. & C7: Synonym & 3.62 & 0.79 \\
\hline 3. & C3: Word class & 3.07 & 1.08 & 3. & C2: Pronunciation & 3.17 & 1.06 \\
\hline 4. & C7: Synonym & 2.96 & 1.13 & 4. & C4: Examples & 3.17 & 1.12 \\
\hline 5. & C4: Examples & 2.89 & 1.02 & 5. & C3: Word class & 2.90 & 1.05 \\
\hline 6. & C5: Phrases & 2.72 & 1.18 & 6. & C5: Phrases & 2.74 & 0.86 \\
\hline 7. & C6: Context & 2.26 & 1.04 & 7. & C6: Context & 2.50 & 0.99 \\
\hline
\end{tabular}

Table 13: Ranking of the seven reference needs by mean consultation frequency

We further examine the relationship between information types and learners' levels, whether there was a significant effect on the frequency in which information types were consulted. Indeed, the type of information most frequently searched by pre-intermediate and intermediate students is meaning, with mean scores of 4.35 and 4.19 respectively for the two groups. This is followed by pronunciation (3.28) and word class (3.07) for the pre-intermediate students. In contrast, synonyms are the second most consulted information by intermediate students (3.62), and pronunciation follows with a mean score of 3.17. The test results have shown that there was an increasing need for synonyms, but not for the remaining types of information.

\section{Conclusion}

User studies, which are based on the user questionnaire survey, can answer a number of questions that are relevant to the greatest part of practical lexicography. However, for a survey to be maximally useful, researchers need to be really careful about the exact form of the question. They need to tackle the specific questions so that they can present useful information to readers.

The results of this study confirm that both pre-intermediate and intermediate students use bilingual dictionaries more often than monolingual dictionaries. The two groups further show indifference when asked to identify dictionary choices and ratings. Moreover, the attempt to bring the lexicographic information to the students proved useful to some extent. It is interesting to see that the students are able to identify language difficulties and use dictionaries to look for particular information.

Although this study is capable of providing the necessary information about the profile of Indonesian speakers as dictionary users, a questionnaire- 
based study has its own shortcomings for not being able to explain the reasons for users' choices. For this reason, adopting a multi-method or mixed approach would be useful in order to better explain the manner of consultation behaviour in this Indonesian context for the future.

\section{References}

\section{Dictionaries}

Babla. Online Dictionaries by bab.la — Loving Languages. Available at: https://en.bab.la/

(CALD) McIntosch, C. (Ed.). 2013. Cambridge Advanced Learner's Dictionary. 4th Edition. Cambridge: Cambridge University Press.

(COBUILD) Harper Collins - UK. 2016. Collins Cobuild Advanced Dictionary of English. Jakarta: Gramedia Pustaka Utama.

Dictionary.com. Available at: www.dictionary.com

Echols, J.M. and H. Shadily (Eds.). 2014. Kamus Indonesia-Inggris. Edisi Ketiga Yang Diperbarui. Jakarta: Gramedia Pustaka Utama.

Echols, J.M. and H. Shadily (Eds.). 2014. Kamus Inggris-Indonesia. Edisi Ketiga Yang Diperbarui. Jakarta: Gramedia Pustaka Utama.

Flitto. For All Your Translation Needs. Available at: https://www.flitto.com/

Kwary, D.A. (Ed.). 2011. Kamus Password English Learner's Dictionary for Speakers of Bahasa Indonesia. Edisi Ketiga + CD ROM. Third edition. Jakarta: Kesaint Blanc.

(LDCE) Delacroix, L. (Ed.). 2014. Longman Dictionary of Contemporary English. 2014. 6th Edition. London: Pearson Education ESL.

Livingstone, C. (Ed.). 2011. Oxford Mini Dictionary and Thesaurus. Oxford: Oxford University Press.

(MEDAL) Rundell, M. (Ed.). 2002. Macmillan English Dictionary for Advanced Learners. Second Edition. London: Macmillan Education.

(OALD) Deuter, M. et al. (Eds.). 2015. Oxford Advanced Learner's Dictionary. 9th Edition. International Student's Edition. Oxford: Oxford University Press.

U-Dictionary. Available at: http://www.u-dictionary.com/home/

Urbandictionary.com. Available at: https://www.urbandictionary.com/

\section{Other}

Amalia, D. 2014. Formulasi Pendefinisian dan Model Pengentrian Verba dalam Kamus Pemelajar Bahasa Indonesia. Depok: Universitas Indonesia.

Atkins, B.T.S. and K. Varantola. 1998. Language Learners Using Dictionaries: The Final Report on the EURALEX/AILA Research Project on Dictionary Use. Atkins, B.T.S. (Ed.). 1998. Using Dictionaries. Studies of Dictionary Use by Language Learners and Translators: 21-82. Lexico- 
graphica. Series Maior 88. Tübingen: Max Niemeyer.

Badan Bahasa Upayakan Leksikografi Berkembang di Indonesia. 2017. Retrieved 25 November 2017, from: http://badanbahasa.kemdikbud.go.id/lamanbahasa/berita/2408

Baxter, J. 1980. The Dictionary and Vocabulary Behavior: A Single Word or a Handful? TESOL Quarterly 14(3): 325-336.

Béjoint, H. 1981. The Foreign Student's Use of Monolingual English Dictionaries: A Study of Language Needs and Reference Skills. Applied Linguistics 2(3): 207-222.

Bensoussan, M., D. Sim and R. Weiss. 1984. The Effect of Dictionary Usage on EFL Test Performance Compared with Student and Teacher Attitudes and Expectations. Reading in a Foreign Language 2(2): 262-276.

Campoy-Cubillo, M.C. 2015. Assessing Dictionary Skills. Lexicography. Journal of ASIALEX 2(1): 119-141.

Frankenberg-Garcia, A. 2015. Dictionaries and Encoding Examples to Support Language Production. International Journal of Lexicography 28(4): 490-512.

Hartmann, R.R.K. 2000. European Dictionary Culture. The Exeter Case Study of Dictionary Use among University Students, against the Wider Context of the Reports and Recommendations of the Thematic Network Project in the Area of Languages (1996-1999). Heid, U. et al. (Eds.). 2000. Proceedings of the Ninth Euralex International Congress, EURALEX 2000, Stuttgart, Germany, August 8th-12th, 2000. Vol. 1: 385-391. Stuttgart: Institut für Maschinelle Sprachverarbeitung, University of Stuttgart.

Hatherall, G. 1984. Studying Dictionary Use: Some Findings and Proposals. Hartmann, R.R.K. (Ed.). 1984. LEXeter '83 Proceedings: Papers from the International Conference on Lexicography at Exeter, 9-12 September 1983: 183-189. Tübingen: Max Niemeyer.

Kwary, D.A. 2018. The Variables for Drawing Up the Profile of Dictionary Users. Lexicography. Journal of ASIALEX 4(2): 105-118. Heidelberg: Springer-Verlag GmbH.

Lew, R. 2004. Which Dictionary for Whom? Receptive Use of Bilingual, Monolingual and Semi-Bilingual Dictionaries by Polish Learners of English. Poznań, Poland: Motivex.

Moeljadi, D., I. Kamajaya and D. Amalia. 2017. Building the Kamus Besar Bahasa Indonesia (KBBI) Database and Its Applications. Xu, Hai (Ed.). 2017. Proceedings of the 11th International Conference of the Asian Association for Lexicography, ASIALEX 2017, 10-12 June 2017, Guangzhou, China: Lexicography in Asia: Challenges, Innovations and Prospects: 64-80. Guangzhou, China: ASIALEX.

Müller-Spitzer, C., M.J. Domínguez Vázquez, M. Nied Curcio, I.M. Silva Dias and S. Wolfer. 2018. Correct Hypotheses and Careful Reading Are Essential: Results of an Observational Study on Learners Using Online Language Resources. Lexikos 28: 287-315.

Nesi, H. 2014. Dictionary Use by English Language Learners. Language Teaching 47(1): 38-55.

Tomaszczyk, J. 1979. Dictionaries: Users and Uses. Glottodidactica 12: 103-119.

Yanto, E.S. 2016. EFL Teachers' Belief , Knowledge and Practices in Using Dictionaries. Journal of ELT Research 1(1): 53-72. Retrieved from: http://journal.uhamka.ac.id/index.php/jer/article/view/30 


\section{Appendix 1: Learner's Questionnaire on Dictionary Use}

Student identification number:

Instructions: answer truthfully all the questions by crossing (like this $\bigotimes$ ) exactly one box in each row. You have 15 minutes for this part.

A. How often do you use the following types of dictionaries?

$\begin{array}{llll}\text { 6-7 days } & \text { 4-5 days } & \text { 2-3 days } & 0-1 \text { day } \\ \text { a week } & \text { a week } & \text { a week } & \text { a week }\end{array}$

1. Indonesian-English (bilingual)

$\square \quad \square$

2. English-Indonesian (bilingual)

3. English-English (monolingual)

B. What dictionaries do you use most often (give the title, type, medium, publisher, author, edition — as far as you remember). Several dictionary types and titles have also been provided on the next page. And how do you rate them? (Answer 1 until 3 dictionaries)

Title/publisher/author/edition (type; medium) $\quad$ excellent $\quad$ good $\quad$ OK $\quad$ poor $\quad$ awful

e.g., Merriam Webster

(mono / bilingual; print /

electronic (hand-held dictionary / CD-ROM) /

online (web-version / dictionary app))$$
3 .
$$

3.

C. How often do you look for the following information in a dictionary:

1. The meaning (definitions or equivalents)

2. Pronunciation (/'ædvəkert/)

3. Word class $(N, V$, etc. $)$

4. Examples (She had the advantage of ...)

5. Phrases (big/great advantage)

6. Context (Law; Formal; Offensive; etc.)

7. Synonyms (syn beneficial)

8. Other (mention):

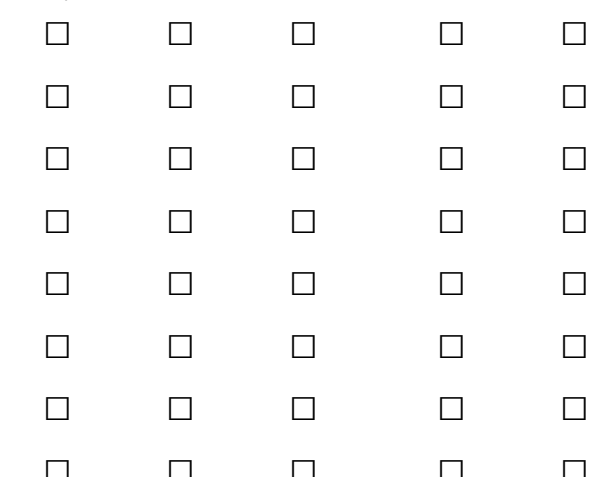


Appendix 2: $\quad$ Dictionary Identification

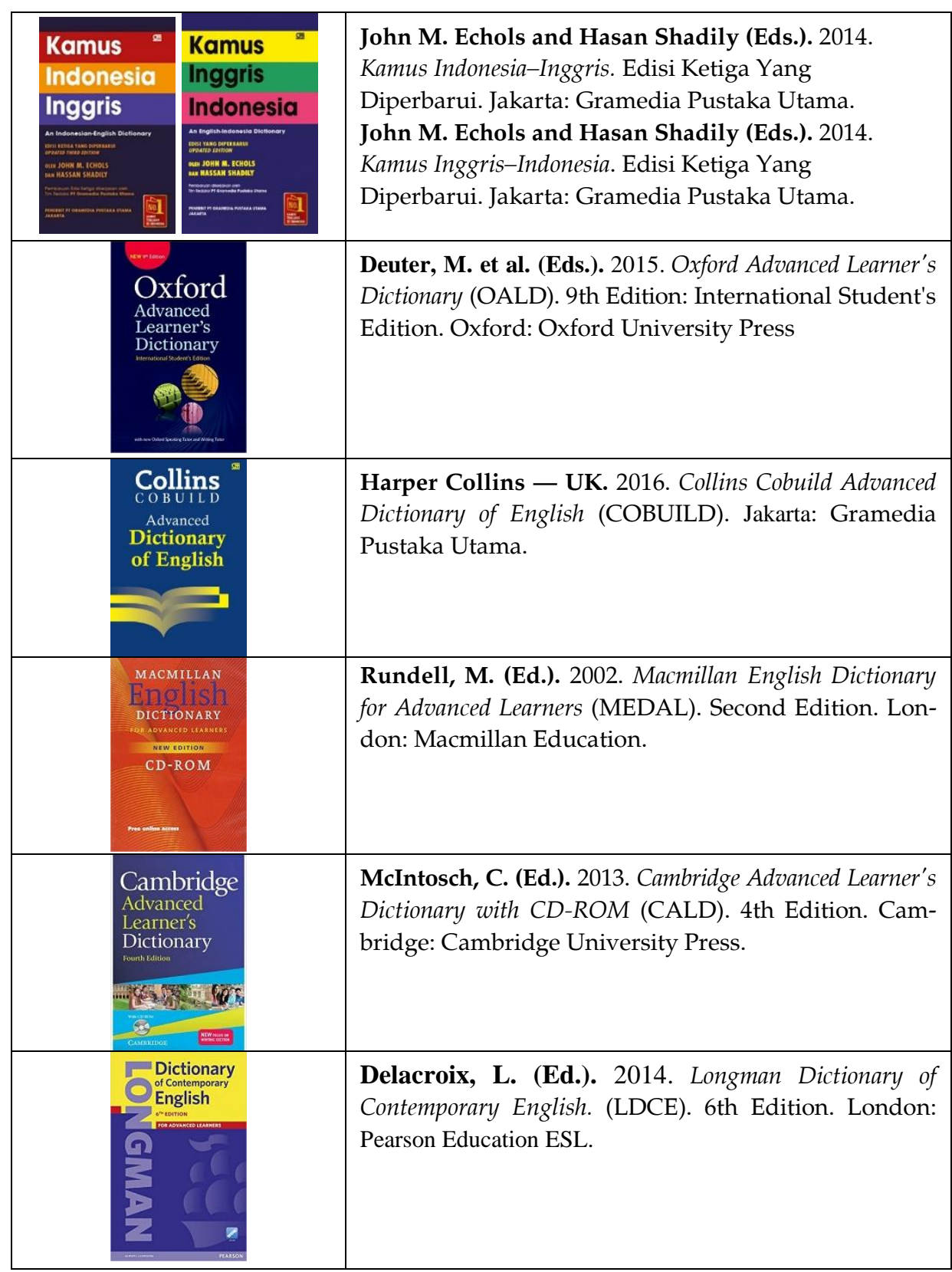




\begin{tabular}{|c|l|}
\hline $\begin{array}{l}\text { PASSWORD } \\
\text { Englsh Learar's }\end{array}$ & $\begin{array}{l}\text { Kwary, D.A. (Ed.). 2011. Kamus Password English } \\
\text { Learner's Dictionary for Speakers of Bahasa Indonesia. } \\
\text { Edisi Ketiga + CD ROM. Third Edition. Jakarta: } \\
\text { Kesaint Blanc. }\end{array}$ \\
\hline$\ldots$ & Others (specify) ... \\
\hline
\end{tabular}

